\title{
Renin-angiotensin system blockers and susceptibility to COVID-19: a multinational open science cohort study
}

Daniel R. Morales ${ }^{1}$, Mitchell M. Conover ${ }^{2}$, Seng Chan You ${ }^{3}$, Nicole Pratt ${ }^{4}$, Kristin Kostka ${ }^{5}$, Talita Duarte-Salles ${ }^{6}$, Sergio Fernández-Bertolín ${ }^{6}$, Maria Aragón ${ }^{6}$, Scott L. DuVall ${ }^{7,8}$, Kristine Lynch ${ }^{7,8}$, Thomas Falconer ${ }^{9}$, Kees van Bochove ${ }^{10}$, Cynthia Sung ${ }^{11}$, Michael E. Matheny ${ }^{12,13}$, Christophe G. Lambert ${ }^{14}$, Fredrik Nyberg ${ }^{15}$, Thamir M. Alshammari ${ }^{16}$, Andrew E. Williams ${ }^{17}$, Rae Woong Park ${ }^{3}$, James Weaver ${ }^{2}$, Anthony G. Sena ${ }^{2,18}$, Martijn J. Schuemie ${ }^{2}$, Peter R. Rijnbeek ${ }^{18}$, Ross D. Williams ${ }^{18}$, Jennifer C.E. Lane ${ }^{19}$, Albert Prats-Uribe ${ }^{19}$, Lin Zhang ${ }^{20,21}$, Carlos Areia ${ }^{22}$, Harlan M. Krumholz ${ }^{23}$, Daniel Prieto-Alhambra ${ }^{19}$, Patrick B. Ryan ${ }^{2,9}$, George Hripcsak ${ }^{9}$ and Marc A. Suchard 24,25

1. Division of Population Health and Genomics, University of Dundee, UK

2. Observational Health Data Analytics, Janssen Research and Development, Titusville, NJ, USA

3. Department of Biomedical Informatics, Ajou University School of Medicine, Suwon, Korea

4. Quality Use of Medicines and Pharmacy Research Centre, Clinical and Health Sciences, University of South Australia, Adelaide, Australia

5. Real World Solutions, IQVIA, Cambridge, MA, USA

6. Fundació Institut Universitari per a la recerca a l'Atenció Primària de Salut Jordi Gol i Gurina (IDIAPJGol), Barcelona, Spain

7. Department of Veterans Affairs, Salt Lake City, UT, USA

8. University of Utah School of Medicine, Salt Lake City, UT, USA

9. Department of Biomedical Informatics, Columbia University, New York, USA

10. The Hyve, Utrecht, Netherlands

11. Translational Discovery, Bill \& Melinda Gates Medical Research Institute, Seattle, WA, USA

12. Geriatric Research Education, and Clinical Care Center, Tennessee Valley Healthcare System VA, Nashville, TN

13. Department of Biomedical Informatics, Vanderbilt University Medical Center, Nashville, TN, USA

14. Department of Internal Medicine, University of New Mexico Health Sciences Center, Albuquerque, NM, USA

15. School of Public Health and Community Medicine, Institute of Medicine, Sahlgrenska Academy, University of Gothenburg, Gothenburg, Sweden

16. Medication Safety Research Chair, King Saud University, Riyadh, Saudi Arabia

17. Tufts Medical Center, Tufts University, Boston, MA, USA

18. Department of Medical Informatics, Erasmus University Medical Center, Rotterdam, Netherlands

19. Centre for Statistics in Medicine, Nuffield Department of Orthopaedics, Rheumatology and Musculoskeletal Sciences, Oxford University, Oxford, UK

20. School of Public Health, Peking Union Medical College and Chinese Academy of Medical Sciences, Beijing, China.

21. Melbourne School of Public Health, The University of Melbourne, Victoria, Australia.

22. Nuffield Department of Clinical Neurosciences, University of Oxford, Oxford, UK

23. Section of Cardiovascular Medicine, Department of Medicine, Yale University, New Haven, CT, USA

24. Department of Biostatistics, UCLA Fielding School of Public Health, University of California, Los Angeles, Los Angeles, CA, USA

25. Department of Computational Medicine, David Geffen School of Medicine at UCLA, University of California, Los Angeles, Los Angeles, CA, USA 
medRxiv preprint doi: https://doi.org/10.1101/2020.06.11.20125849; this version posted June 12, 2020. The copyright holder for this preprint (which was not certified by peer review) is the author/funder, who has granted medRxiv a license to display the preprint in perpetuity. It is made available under a CC-BY-NC 4.0 International license .

\section{Abstract}

\section{Introduction}

Angiotensin converting enzyme inhibitors (ACEs) and angiotensin receptor blockers (ARBs) could influence infection risk of coronavirus disease (COVID-19). Observational studies to date lack pre-specification, transparency, rigorous ascertainment adjustment and international generalizability, with contradictory results.

\section{Methods}

Using electronic health records from Spain (SIDIAP) and the United States (Columbia University Irving Medical Center and Department of Veterans Affairs), we conducted a systematic cohort study with prevalent ACE, ARB, calcium channel blocker (CCB) and thiazide diuretic (THZ) users to determine relative risk of COVID-19 diagnosis and related hospitalization outcomes. The study addressed confounding through large-scale propensity score adjustment and negative control experiments.

\section{Results}

Following over 1.1 million antihypertensive users identified between November 2019 and January 2020, we observed no significant difference in relative COVID-19 diagnosis risk comparing ACE/ARB vs CCB/THZ monotherapy (hazard ratio: 0.98; 95\% $\mathrm{Cl} 0.84-1.14$ ), nor any difference for mono/combination use (1.01; 0.90 - 1.15). ACE alone and ARB alone similarly showed no relative risk difference when compared to $\mathrm{CCB} / \mathrm{THZ}$ monotherapy or mono/combination use. Directly comparing ACE vs. ARB demonstrated a moderately lower risk with ACE, non-significant for monotherapy $(0.85 ; 0.69-1.05)$ and marginally significant for mono/combination users (0.88; 0.79 - 0.99). We observed, however, no significant difference between drug-classes for COVID-19 hospitalization or pneumonia risk across all comparisons.

\section{Conclusion}

There is no clinically significant increased risk of COVID-19 diagnosis or hospitalization with ACE or ARB use. Users should not discontinue or change their treatment to avoid COVID-19. 
medRxiv preprint doi: https://doi.org/10.1101/2020.06.11.20125849; this version posted June 12, 2020. The copyright holder for this preprint (which was not certified by peer review) is the author/funder, who has granted medRxiv a license to display the preprint in perpetuity. It is made available under a CC-BY-NC 4.0 International license .

\section{Introduction}

People with cardiovascular diseases and hypertension are more likely to develop severe complications of coronavirus disease 2019 (COVID-19) resulting in hospitalization and death (Shi et al. 2020; Guo et al. 2020); (Ruan et al. 2020). Speculatively, angiotensin converting enzyme inhibitors (ACEs) and angiotensin-II receptor blockers (ARBs), both renin-angiotensin system (RAS) blockers, may influence susceptibility to COVID-19 and worsen its severity. Driving this hypothesis is the mechanism that SARS-CoV-2 enters human cells by binding to the membrane-bound aminopeptidase angiotensin-converting enzyme 2 (ACE2) (Li et al. 2003; Hoffmann et al. 2020), for which chronic exposure to RAS therapy may alter expression (Ferrario et al. 2005; Vuille-dit-Bille et al. 2015; Soler et al. 2009; Sukumaran et al. 2011, 2012, 2017; Ishiyama et al. 2004; Zhong et al. 2011). This has generated substantial public health concerns resulting in the release of statements from health regulatory agencies and clinical societies advocating that in the absence of direct evidence of harm with COVID-19, these medicines should not be discontinued (European Medicines Agency n.d.; European Society of Cardiology n.d.). However, inconsistencies in recommendations emerged with suggestions that users should either be monitored more closely (Fang, Karakiulakis, and Roth 2020) or that clinical trials investigating their withdrawal should be performed (Bauer and Massberg n.d.). Withholding these medicines, however, may result in worse cardiovascular outcomes with some studies reporting an increased risk of myocardial injury resulting from illness with COVID-19 (Shi et al. 2020).

Several studies have emerged examining this conundrum. While informative, they have either had smaller sample size, used heterogeneous study designs or had methodological limitations (Zhang et al. 2020; Dooley et al. n.d.). For example, all except two recent studies have so far directly compared the risk of COVID-19 with ACE or ARB use with an unexposed control population (de Abajo et al. 2020; Khera et al. 2020). This can result in non-comparable subjects, confounding by indication and the lack of a clear index date for when follow-up should start, all of which may induce bias.

Reliable evidence should also be replicable, generalizable and robust. To draw strong conclusions from observational studies, we must observe consistent findings produced from transparent, well-designed analyses across multiple populations and data capture processes to ensure that any associations are not due to systematic error or applicable only in narrow contexts. This study aimed to determine whether exposure to ACEs/ARBs is associated with an increased susceptibility to COVID-19 using a large multi-national federated active comparator cohort study facilitated by a common data model using the Observational Health Data Sciences and Informatics (OHDSI) (Hripcsak et al. 2015) network. 
medRxiv preprint doi: https://doi.org/10.1101/2020.06.11.20125849; this version posted June 12, 2020. The copyright holder for this preprint (which was not certified by peer review) is the author/funder, who has granted medRxiv a license to display the preprint in perpetuity. It is made available under a CC-BY-NC 4.0 International license .

\section{Methods}

\section{Study design}

An international team of clinical, academic, government and industry stakeholders openly drafted the protocol for the International Covid-ACE Receptor Inhibition Utilization and Safety (ICARIUS) studies (https://github.com/ohdsi-studies/Covid19Icarius) and registered the protocol in the EU PAS register (EUPAS35296). Under our protocol, we conducted a systematic and comprehensive prevalent-user active comparator cohort study measuring the association between RAS use and susceptibility to COVID-19 among hypertensive patients using antihypertensive medication.

\section{Data sources}

We identified patients in routinely-collected electronic health records (EHRs) and claims data from the United States (US) and Spain. All data sources had been mapped to the Observational Medical Outcomes Partnership (OMOP) Common Data Model (CDMv5) that the open-science OHDSI collaborative maintains (Hripcsak et al. 2015). Two particular benefits of this standardization are that contributing centers can participate in distributed network analyses without needing to share patient-level information and that we can ensure data provenance, while applying common analytical code across all data sources in a consistent manner. The data sources included:

- Columbia University Irving Medical Center data warehouse (CUIMC) EHRs covering approximately six million patients from the New York-Presbyterian Hospital/Columbia University Irving Medical Center in the US. CUIMC includes data on clinical diagnoses, prescriptions, laboratory tests, demographics, and COVID-19 tests and diagnosis;

- Information Systems for Research in Primary Care (SIDIAP) database, covering approximately $80 \%$ of the population of Catalonia, Spain, with approximately six million patients. SIDIAP contains data since 2006 from general practice EHRs linked to hospital admissions with information on diagnoses, prescriptions, laboratory tests, and lifestyle and sociodemographics and the central database of RT-PCR COVID-19 tests; and

- US Department of Veterans Affairs (VA) database, covering approximately 12 million patients from 170 medical centers across the US and including administrative, clinical, laboratory, and pharmacy data repositories that are linked using unique patient identifiers. 
medRxiv preprint doi: https://doi.org/10.1101/2020.06.11.20125849; this version posted June 12, 2020. The copyright holder for this preprint (which was not certified by peer review) is the author/funder, who has granted medRxiv a license to display the preprint in perpetuity. It is made available under a CC-BY-NC 4.0 International license .

Each site obtained institutional review board approval or obtained a determination that the de-identified data were not human subjects research.

\section{Cohort eligibility, study period and follow-up}

Each cohort consisted of adults aged 18 years or older who received at least one eligible outpatient prescription for an antihypertensive drug between $1^{\text {st }}$ November 2019 and $31^{\text {st }}$ January 2020. The index date was set as the date of the last prescription in this time window. We required patients to be observable in their data source for at least one year prior to the index date and have a recorded history of hypertension at any point prior to or including the index date (Figure 1). Cohort exit was the earliest of: the occurrence of an outcome; the end of exposure; death; loss or deregistration from the database; or date of last data collection.

\section{Exposures}

The exposures of interest were four first-line antihypertensive drug classes: ACEs, ARBs, dihydropyridine calcium channel blockers (CCBs) and thiazide or thiazide-like diuretics (THZs), defined separately as either 1) monotherapy or 2) monotherapy or combination therapy (simply called combination in this paper) users with other antihypertensives. Our primary comparison examined outpatient RAS blocker exposure (ACE or ARB) to CCBs or THZs exposure (included as active comparators). Further investigation compared class exposure to ACEs to exposure to ARBs separately, and individual classes to various active comparators, leading to ten different target-comparator pairings for monotherapy and combo-therapy each, as listed in the online supplement. For patients on monotherapy, we required the absence of any other antihypertensive treatment between -180 days and 0 days prior to the index date. We defined continuous drug exposures from the start of follow-up by grouping sequential prescriptions that have at most 30 days gap between prescriptions, and defined end of exposure as the end of the last prescription's drug supply in such a sequence. 
medRxiv preprint doi: https://doi.org/10.1101/2020.06.11.20125849; this version posted June 12, 2020. The copyright holder for this preprint (which was not certified by peer review) is the author/funder, who has granted medRxiv a license to display the preprint in perpetuity. It is made available under a CC-BY-NC 4.0 International license .

\section{Outcomes}

We investigated four COVID-19 related outcomes: 1) COVID-19 diagnosis; 2) COVID-19 hospitalization; 3) hospitalization with pneumonia and; 4) hospitalization with pneumonia, acute respiratory distress syndrome (ARDS), acute kidney injury (AKI) or sepsis (PAAS). In brief, positive tests results or diagnostic codes defined COVID-19 status. The full details of the participant cohorts and outcomes used for development and validation can be found in the online protocol.

\section{Study size}

We undertook this study using all patients meeting the eligibility criteria within each database. We therefore performed no a priori sample size calculation; instead, we provide a minimum detectable rate ratio (MDRR) for each target-comparator-outcome triplet across each data source.

\section{Statistical methods}

To adjust for potential measured confounding and improve the balance between comparison cohorts, we built large-scale propensity score (PS) models (Rosenbaum and Rubin 1983) for each comparison and data source using a consistent data-driven process through regularized regression (Tian, Schuemie, and Suchard 2018). This process used a large set of predefined baseline patient characteristics, including age, gender, race (US data) and other demographics and prior conditions, drug exposures, procedures and health service utilization behaviors, to provide the most accurate prediction of treatment and balance patient cohorts across many characteristics. For computational efficiency, we excluded all features that occurred in fewer than $0.1 \%$ of patients within the target and comparator cohorts prior to PS model fitting.

In separate analyses, we stratified into 5 PS quintiles or variable-ratio matched patients by PS, and used Cox proportional hazards models to estimate hazard ratios (HRs) between alternative target and comparator treatments for the risk of each outcome in each data source. The regression conditioned on the PS strata/matching-unit with treatment allocation as the sole explanatory variable. We aggregated HR estimates across data sources to produce meta-analytic estimates using a random-effects meta-analysis (DerSimonian and Laird 1986). For both monotherapy and combination use of the ACE, ARB, CCB, THZ, ACE or ARB (ACE/ARB) and $\mathrm{CCB}$ or $\mathrm{THZ}$ (CCB/THZ) class groups (10 pairwise comparisons) to study four outcomes in 
medRxiv preprint doi: https://doi.org/10.1101/2020.06.11.20125849; this version posted June 12, 2020. The copyright holder for this preprint (which was not certified by peer review) is the author/funder, who has granted medRxiv a license to display the preprint in perpetuity. It is made available under a CC-BY-NC 4.0 International license .

three data sources (plus one meta-analysis) using two PS-adjustment approaches, we generated $2 \times 10 \times 4 \times(3+1) \times 2=1280$ study effects.

Residual study bias from unmeasured and systematic sources often remains in observational studies even after controlling for measured confounding through PS-adjustment (Schuemie et al. 2014, 2016). For each study effect, we conducted negative control outcome experiments, where the null hypothesis of no effect is believed to be true, using 76 controls identified through a data-rich algorithm (Voss et al. 2017) and validated in a previous antihypertensive comparative study (Suchard et al. 2019). Using the empirical null distributions from these experiments, we calibrated each study effect $\mathrm{HR}$ estimate, its $95 \%$ confidence interval $(\mathrm{Cl})$ and the $p$-value to reject the null hypothesis of no differential effect (Schuemie et al. 2018). We declared a HR as significantly different from no effect when its calibrated $p<0.05$ without correcting for multiple testing.

Blinded to the results, clinicians and epidemiologists evaluated study diagnostics for these treatment comparisons to assess if they were likely to yield unbiased estimates. The suite of diagnostics included (1) MDRR, (2) preference score (a transformation of the PS that adjusts for prevalence differences between populations) distributions to evaluate empirical equipoise (Walker et al. 2013) and population generalizability, (3) extensive patient characteristics to evaluate cohort balance before and after PS-adjustment, (4) negative control calibration plots to assess residual bias, and (5) Kaplan-Meier plots to examine HR proportionality assumptions. We defined target and comparator cohorts to stand in empirical equipoise if the majority of patients in both carry preference scores between 0.3 and 0.7 and to achieve sufficient balance if all after-adjustment baseline characteristics return absolute standardized mean differences $(S M D)<0.1$ (Austin 2009).

\section{Study execution}

We conducted this study using the open-source OHDSI CohortMethod R package (https://ohdsi.github.io/CohortMethod/) with large-scale analytics made possible through the Cyclops R package (Suchard et al. 2013). The pre-specified ICARIUS protocol and start-to-finish open and executable source code are available at:

https://github.com/ohdsi-studies/Covid19/carius. To promote transparency and facilitate sharing and exploration of the complete result set, an interactive web application (https://data.ohdsi.org/IcariusSusceptibility) serves up study diagnostics and results for all study effects. 
medRxiv preprint doi: https://doi.org/10.1101/2020.06.11.20125849; this version posted June 12, 2020. The copyright holder for this preprint (which was not certified by peer review) is the author/funder, who has granted medRxiv a license to display the preprint in perpetuity. It is made available under a CC-BY-NC 4.0 International license .

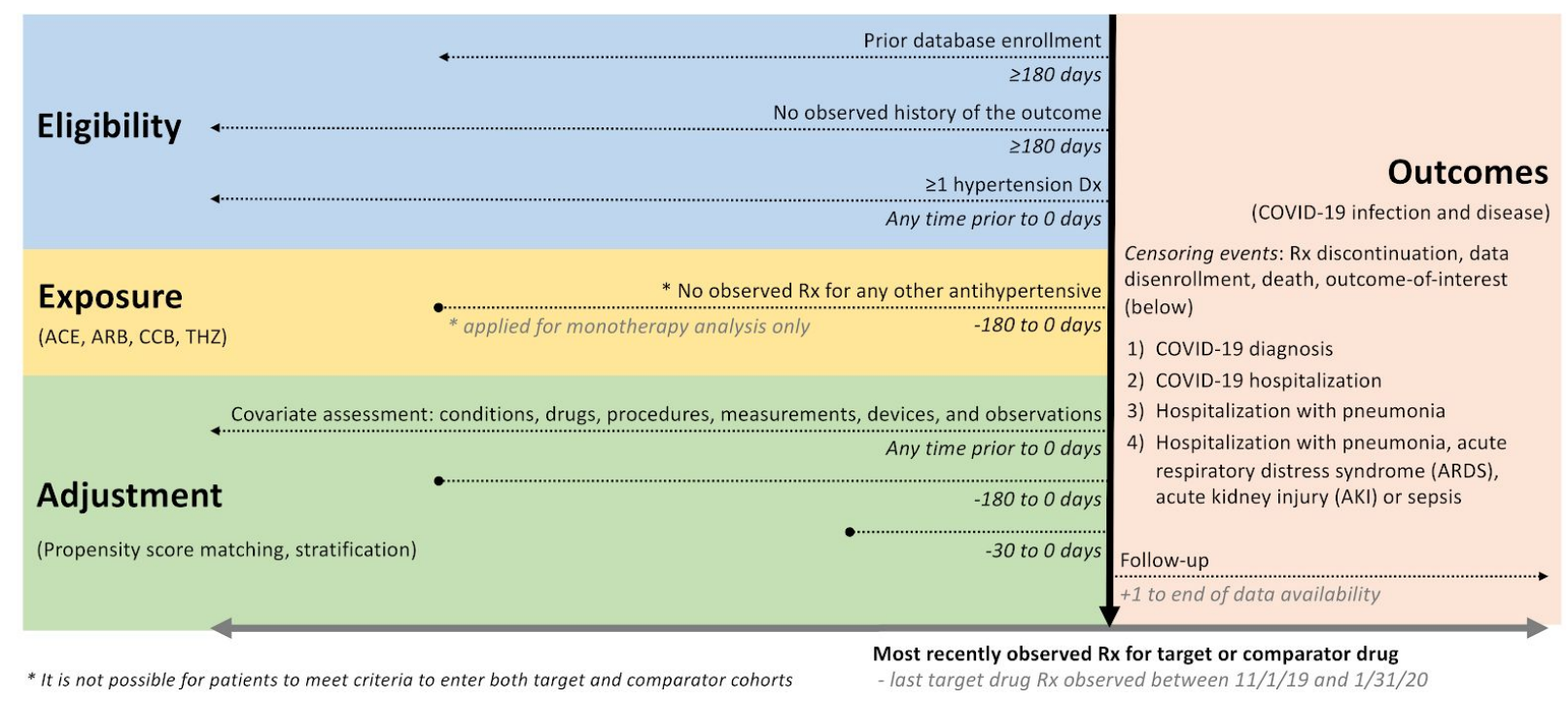

Figure 1. International Covid-ACE Receptor Inhibition Utilization and Safety (ICARIUS) susceptibility study design schematic. We highlight eligibility criteria, exposure definitions, adjustment strategies, index date specification (horizontal black arrow) and outcome definitions and time-at-risk. Exposure involves prescriptions to drugs with RxNorm ingredients that map to the first-line antihypertensive angiotensin converting enzyme inhibitor (ACE), angiotensin receptor blocker (ARB), dihydropyridine calcium channel blockers (CCB) and thiazide or thiazide-like diuretic (THZ) classes. 
medRxiv preprint doi: https://doi.org/10.1101/2020.06.11.20125849; this version posted June 12, 2020. The copyright holder for this preprint (which was not certified by peer review) is the author/funder, who has granted medRxiv a license to display the preprint in perpetuity. It is made available under a CC-BY-NC 4.0 International license .

\section{Results}

\section{Population and incidence}

A total of 363,785 hypertensive patients exposed to ACE/ARB monotherapy were compared to $248,915 \mathrm{CCB} / \mathrm{THZ}$ monotherapy users contributing 121,213 and 81,261 person years (pyrs) of follow-up respectively. The overall incidence of COVID-19 diagnosis among monotherapy was 5.6 vs 4.8 per 1,000 pyrs among $A C E / A R B$ and $C C B / T H Z$ users respectively, although incidence rates varied by data source.

Corresponding patient cohort size and diagnosis incidence rates were: 268,711 and 5.6 per 1,000 pyrs for ACE (alone) monotherapy users and 92,485 and 5.1 per 1,000 pyrs for ARB (alone) monotherapy, when compared to CCB/THZ monotherapy users or each other. Cohorts for combination users (as monotherapy or in-combination) ranged as large as 711,799 for ACE/ARB users and 473,076 for CCB/THZ users.

The aggregated patient cohort size, follow-up duration, incidences of each COVID-19 related outcome and MDRR for each drug comparison and database are shown in Table 1.

Supplementary Tables 1 - 4 provide further cohort size and outcome event information for all 10 pairwise cohort comparisons across all 4 outcomes.

\section{Characteristics of patients}

Baseline characteristics of ACE/ARB monotherapy users compared to CCB/THZ monotherapy users, before and after PS stratification, are shown in Table 2. There were baseline differences in sex, hyperlipidaemia, diabetes, renal impairment, heart failure, heart disease, atrial fibrillation, drugs for diabetes, lipid modifying agents, antithrombotics, antacids, opioids, and race that varied by data source. Further information on the population characteristics for each cohort comparison and design evaluated for each data source are shown in Supplementary Tables 5 - 64, one for each of the $2 \times 10 \times 3=60$ comparisons across data sources.

\section{PS model adjustment and cohort balance}

The number of baseline patient characteristics available differed across comparison-cohorts and data sources, ranging from 6,447 to 9,860 in SIDIAP, 10,638 to 12,425 in VA-OMOP and 11,776 to 21,440 in CUIMC. After large-scale PS construction and then stratification or matching, SMDs for all baseline characteristics were $<0.1$ in SIDIAP and VA-OMOP for each drug 
medRxiv preprint doi: https://doi.org/10.1101/2020.06.11.20125849; this version posted June 12, 2020. The copyright holder for this preprint (which was not certified by peer review) is the author/funder, who has granted medRxiv a license to display the preprint in perpetuity. It is made available under a CC-BY-NC 4.0 International license .

comparison, apart from the comparison between combination users of ARBs and CCBs/THZs in VA-OMOP. SMDs for all baseline characteristics before and after PS adjustment for ACE/ARB monotherapy users compared to CCB/THZ monotherapy users for all data sources are plotted in Figure 2. In CUIMC, all but one drug comparison (ACE vs ARB monotherapy) with PS stratification showed residual cohort imbalances with a SMD $\geq 0.1$, which involved baseline characteristics related to pregnancy, renal transplantation, and heart failure and use of sacubitril. However, these cohort comparisons all passed study diagnostics for the PS matching design. Supplementary Figures 1 - 60 demonstrate study diagnostics for all comparisons and include negative control effect estimate distributions.

\section{Risk of COVID-19 diagnosis}

Calibrated HRs for the relative risk of incident COVID-19 diagnosis are presented in Table 3 and Figure 3 for PS stratified and PS matched analyses. In SIDIAP, the risk of of COVID-19 diagnosis was not significantly different among ACE/ARB users compared to CCB/THZ use with PS stratification (HR 1.02, 95\% Cl 0.86-1.21 for monotherapy and $\mathrm{HR} 1.06,95 \% \mathrm{Cl} 0.92-1.24$ with combination use). Corresponding hazard ratios in VA-OMOP were HR 0.91 ( $95 \% \mathrm{Cl} 0.71-1.17)$ and $\mathrm{HR} 0.98$ (95\% $\mathrm{Cl} 0.81-1.18)$. PS stratification did not pass study diagnostics in CUIMC and is therefore grayed out in the table to caution against interpretation. The corresponding HRs for CUIMC using PS matching were HR 0.67 (95\% Cl 0.20-2.20) and HR 2.36 (95\% Cl 0.98-5.68) respectively. Meta-analytic HRs following PS stratification for ACE/ARB use were $0.98(95 \% \mathrm{Cl}$ 0.84 - 1.14) for monotherapy, and $1.01(95 \% \mathrm{Cl} 0.90$ - 1.15) with combination use.

When comparing ACE and ARB use separately to CCB/THZ use, we observed no significant difference with COVID-19 diagnosis for comparisons passing study diagnostics (Table 3). For ACE use, meta-analytic HRs for monotherapy were 0.91 (95\% Cl 0.68 - 1.21), but with heterogeneity $>40 \%$, and $0.95(95 \% \mathrm{Cl} 0.83-1.08)$ for combination use. For ARB use, meta-analytic HRs for monotherapy were $1.10(95 \% \mathrm{Cl} 0.89-1.35)$ for PS stratification, and 1.08 $(95 \% \mathrm{Cl} 0.89$ - 1.31) with combination use.

When comparing ACE use directly to ARB use, no significant difference in the risk of COVID-19 diagnosis was observed in individual databases, apart from combination use in VA-OMOP (HR $0.84,95 \% \mathrm{Cl} 0.71$ - 0.99). Meta-analytic HRs for monotherapy were 0.85 (95\% $\mathrm{Cl} 0.69-1.05)$ for PS stratification and $0.88(95 \% \mathrm{Cl} 0.79-0.99)$ for combination use. PS matching, where comparisons from CUIMC passed all PS diagnostics, produced similar results (Table 3 ). 
medRxiv preprint doi: https://doi.org/10.1101/2020.06.11.20125849; this version posted June 12, 2020. The copyright holder for this preprint (which was not certified by peer review) is the author/funder, who has granted medRxiv a license to display the preprint in perpetuity. It is made available under a CC-BY-NC 4.0 International license .

\section{Risk of COVID-19 hospitalization, pneumonia and PAAS}

Calibrated HRs for the risk of COVID-19 hospitalization are presented in Figure 3. We observed no significant association between incident COVID-19 hospitalization for the comparison with ACE/ARB use, evaluated either together or separately, compared to CCB/THZ use. For ACE use compared to ARB use using PS stratification, meta-analytic HRs for monotherapy were 0.88 $(95 \% \mathrm{Cl} 0.66-1.17)$ and $0.93(95 \% \mathrm{Cl} 0.82-1.07)$ with combination use.

No significant associations with the risk of pneumonia were observed with any drug comparison that satisfied study diagnostics. No significant associations with the risk of PAAS were observed with any drug comparison that satisfied study diagnostics in SIDIAP and CUIMC. In VA-OMOP no significant difference was observed in comparisons between ARB versus $\mathrm{CCB} / \mathrm{THZ}$ use or $\mathrm{ACE}$ versus $\mathrm{ARB}$ use, while small significant associations were observed with ACE versus CCB/THZ (Supplementary Table 192). 
medRxiv preprint doi: https://doi.org/10.1101/2020.06.11.20125849; this version posted June 12, 2020. The copyright holder for this preprint (which was not certified by peer review) is the author/funder, who has granted medRxiv a license to display the preprint in perpetuity.

It is made available under a CC-BY-NC 4.0 International license.

Table 1: Populations and COVID-19 diagnoses for angiotensin converting enzyme (ACE) inhibitor, angiotensin receptor blocker (ARB), calcium channel block (CCB) and thiazide or thiazide-like diuretics (THZ) monotherapy and in-combination user cohorts. For each target (T) and comparator $(C)$ cohort, we report population size, total exposure time, outcome events and minimally detectable risk ratio (MDRR).

\begin{tabular}{|c|c|c|c|c|c|c|c|}
\hline & \multicolumn{2}{|c|}{ Patients } & \multicolumn{2}{|c|}{ Time (years) } & \multicolumn{2}{|c|}{ Events } & \multirow[b]{2}{*}{ MDRR } \\
\hline & T & C & $\mathrm{T}$ & C & $\mathrm{T}$ & C & \\
\hline \multicolumn{8}{|c|}{$\mathrm{ACE} / \mathrm{ARB}$ vs $\mathrm{CCB} / \mathrm{THZ}$} \\
\hline \multicolumn{8}{|l|}{ Monotherapy } \\
\hline SIDIAP & 37,796 & 14,003 & 10,239 & 3,780 & 500 & 184 & 1.27 \\
\hline VA-OMOP & 320,450 & 229,063 & 110,380 & 76,856 & 145 & 183 & 1.37 \\
\hline CUIMC & 5,539 & 5,849 & 594 & 625 & 28 & 24 & 2.18 \\
\hline \multicolumn{8}{|l|}{ + Combination } \\
\hline SIDIAP & 45,239 & 19,007 & 12,264 & 5,175 & 627 & 250 & 1.23 \\
\hline VA-OMOP & 656,274 & 443,061 & 228,678 & 150,755 & 345 & 335 & 1.24 \\
\hline CUIMC & 10,286 & 11,008 & 1,128 & 1,185 & 59 & 58 & 1.68 \\
\hline \multicolumn{8}{|l|}{ ACE vs CCB/THZ } \\
\hline \multicolumn{8}{|l|}{ Monotherapy } \\
\hline SIDIAP & 30,787 & 14,003 & 8,293 & 3,780 & 398 & 184 & 1.28 \\
\hline VA-OMOP & 235,348 & 229,063 & 80,760 & 76,856 & 96 & 183 & 1.40 \\
\hline CUIMC & 2,576 & 5,849 & 277 & 625 & 10 & 24 & 2.84 \\
\hline \multicolumn{8}{|l|}{ + Combination } \\
\hline SIDIAP & 36,323 & 29,239 & 9,803 & 7,941 & 485 & 399 & 1.21 \\
\hline VA-OMOP & 457,557 & 639,500 & 158,721 & 221,239 & 218 & 494 & 1.24 \\
\hline CUIMC & 4,811 & 16,302 & 511 & 1,754 & 18 & 83 & 1.94 \\
\hline \multicolumn{8}{|l|}{ ARB vs $\mathrm{CCB} / \mathrm{THZ}$} \\
\hline \multicolumn{8}{|l|}{ Monotherapy } \\
\hline SIDIAP & 6,753 & 14,003 & 1,815 & 3,780 & 95 & 184 & 1.43 \\
\hline VA-OMOP & 82,872 & 229,063 & 28,689 & 76,856 & 46 & 183 & 1.52 \\
\hline CUIMC & 2,860 & 5,849 & 301 & 625 & 17 & 24 & 2.54 \\
\hline \multicolumn{8}{|l|}{ + Combination } \\
\hline SIDIAP & 9,194 & 39,427 & 2,457 & 10,714 & 137 & 519 & 1.32 \\
\hline VA-OMOP & 201,503 & 854,224 & 70,267 & 295,986 & 127 & 574 & 1.31 \\
\hline CUIMC & 5,669 & 14,271 & 629 & 1,533 & 41 & 77 & 1.77 \\
\hline \multicolumn{8}{|l|}{ ACE vs ARB } \\
\hline \multicolumn{8}{|l|}{ Monotherapy } \\
\hline SIDIAP & 30,787 & 6,753 & 8,293 & 1,815 & 398 & 95 & 1.39 \\
\hline VA-OMOP & 235,348 & 82,872 & 80,760 & 28,689 & 96 & 46 & 1.71 \\
\hline CUIMC & 2,576 & 2,860 & 277 & 301 & 10 & 17 & 2.94 \\
\hline \multicolumn{8}{|l|}{ + Combination } \\
\hline SIDIAP & 56,465 & 19,148 & 15,333 & 5,176 & 758 & 283 & 1.22 \\
\hline VA-OMOP & 865,931 & 395,156 & 303,491 & 140,071 & 441 & 282 & 1.25 \\
\hline CUIMC & 7,880 & 10,769 & 826 & 1,179 & 39 & 66 & 1.74 \\
\hline
\end{tabular}


medRxiv preprint doi: https://doi.org/10.1101/2020.06.11.20125849; this version posted June 12, 2020. The copyright holder for this preprint (which was not certified by peer review) is the author/funder, who has granted medRxiv a license to display the preprint in perpetuity.

It is made available under a CC-BY-NC 4.0 International license.

Table 2: Baseline patient characteristics for ACE/ARB (T) and CCB/THZ (C) monotherapy prevalent-use in the SIDIAP, VA-OMOP and CUIMC data sources. We report the proportion of use satisfying selected based-line characteristics and the standardized difference of population proportions (SDf) before and after stratification. Less extreme SDf through stratification suggest improved balance between patient cohorts through propensity score adjustment.

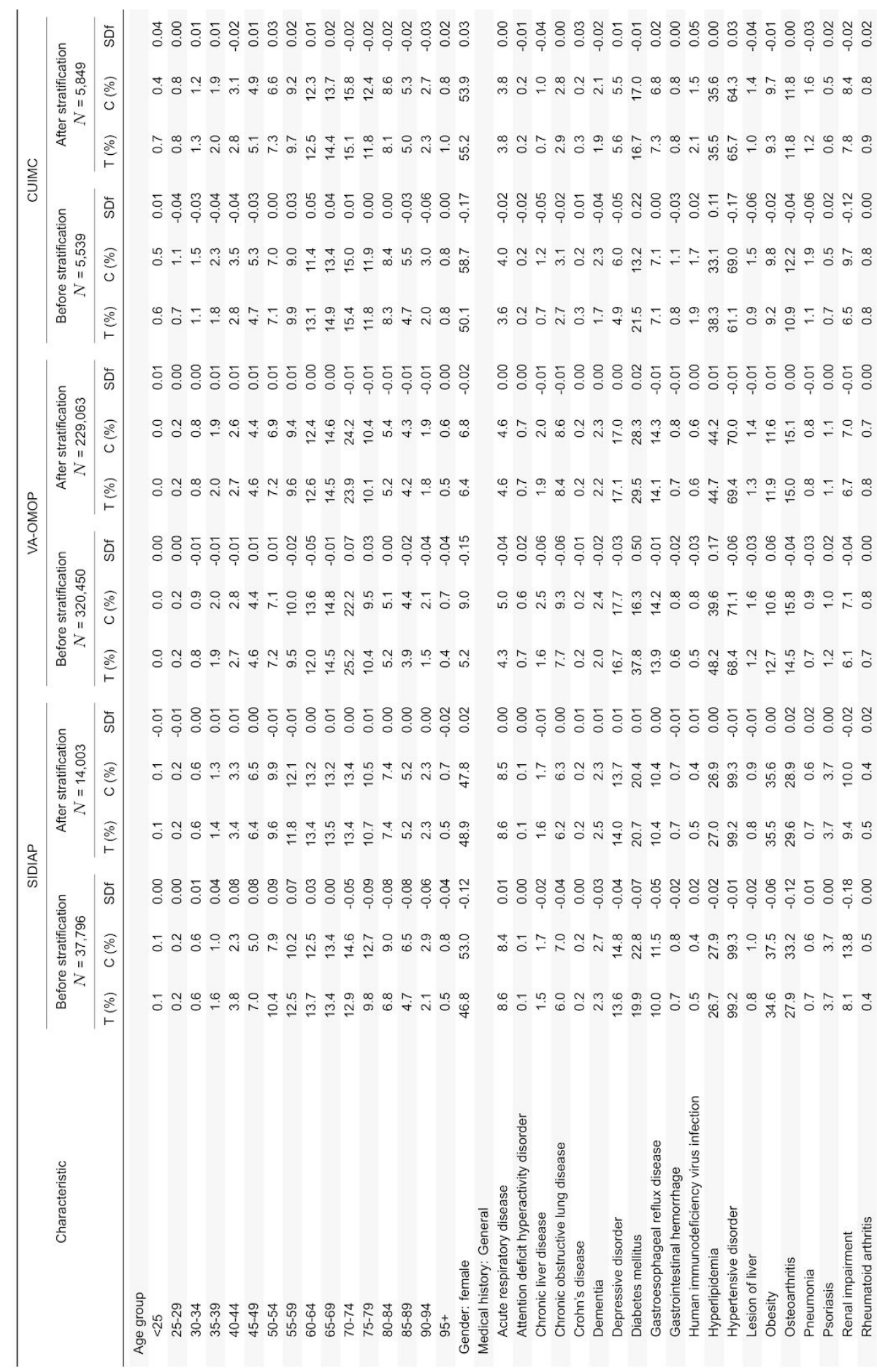


medRxiv preprint doi: https://doi.org/10.1101/2020.06.11.20125849; this version posted June 12, 2020. The copyright holder for this preprint (which was not certified by peer review) is the author/funder, who has granted medRxiv a license to display the preprint in perpetuity.

It is made available under a CC-BY-NC 4.0 International license.

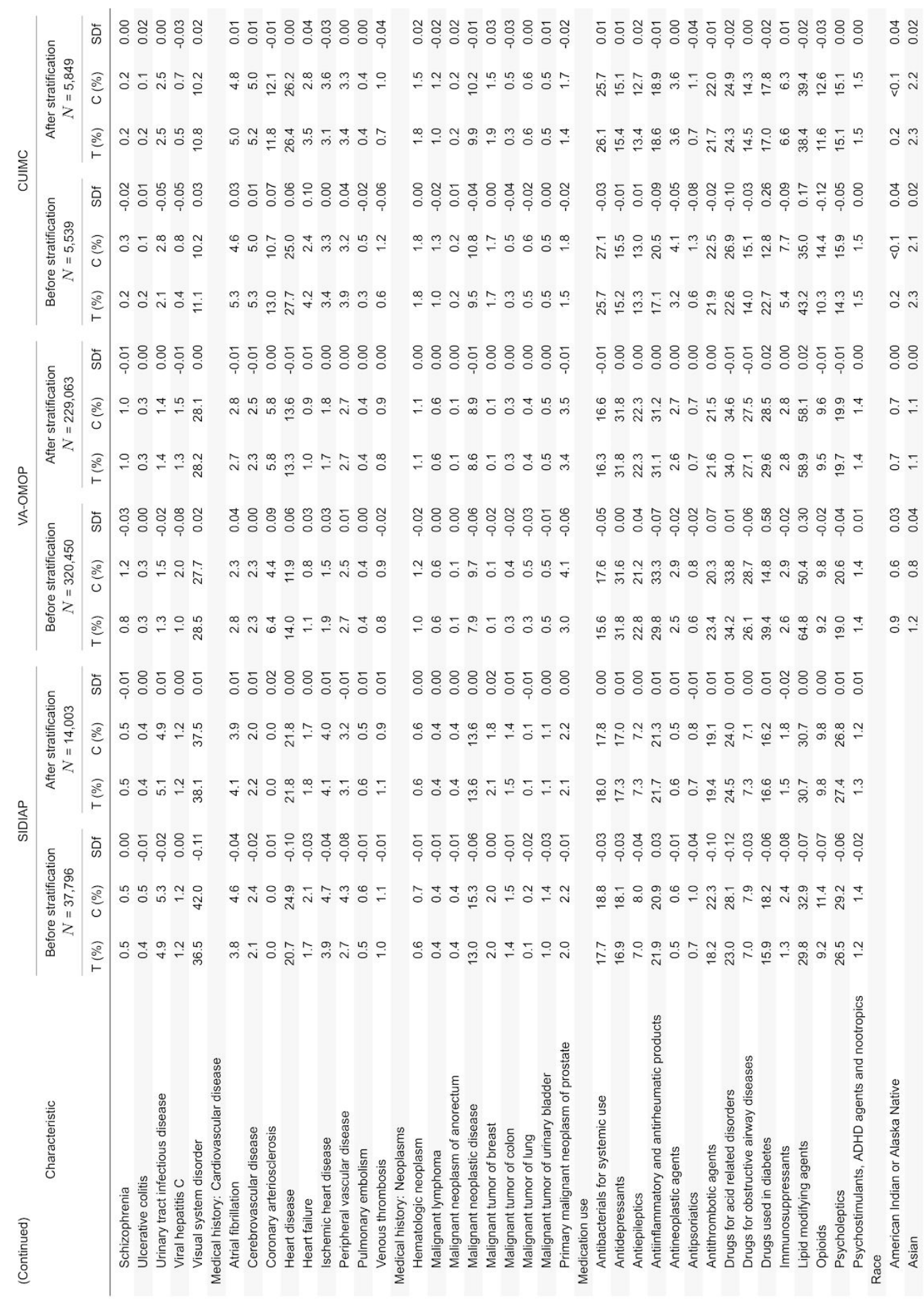


medRxiv preprint doi: https://doi.org/10.1101/2020.06.11.20125849; this version posted June 12, 2020. The copyright holder for this preprint (which was not certified by peer review) is the author/funder, who has granted medRxiv a license to display the preprint in perpetuity.

$$
\text { It is made available under a CC-BY-NC } 4.0 \text { International license. }
$$

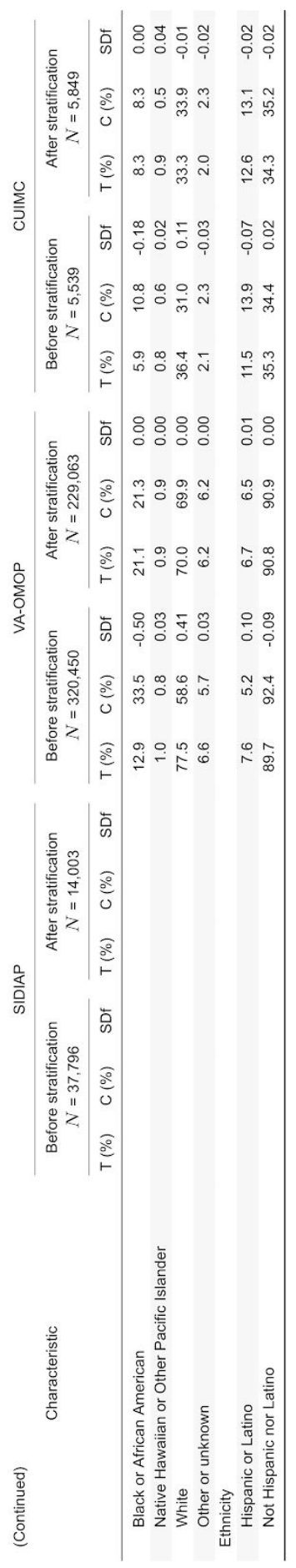


medRxiv preprint doi: https://doi.org/10.1101/2020.06.11.20125849; this version posted June 12, 2020. The copyright holder for this preprint (which was not certified by peer review) is the author/funder, who has granted medRxiv a license to display the preprint in perpetuity. It is made available under a CC-BY-NC 4.0 International license .

Figure 2. Cohort balance diagnostics comparing ACE/ARB and CCB/THZ monotherapy prevalent-use for the risk COVID-19 diagnosis. We plotted the absolute standardized difference of population proportions of all available patient characteristics $(6,571$ in SIDIAP, 11,183 in VA-OMOP, and 18,291 in CUIMC) before and after propensity score stratification or matching across data sources. Using stratification, CUIMC fails study diagnostics for this comparison as the absolute standardized difference is not consistently $<0.1$.
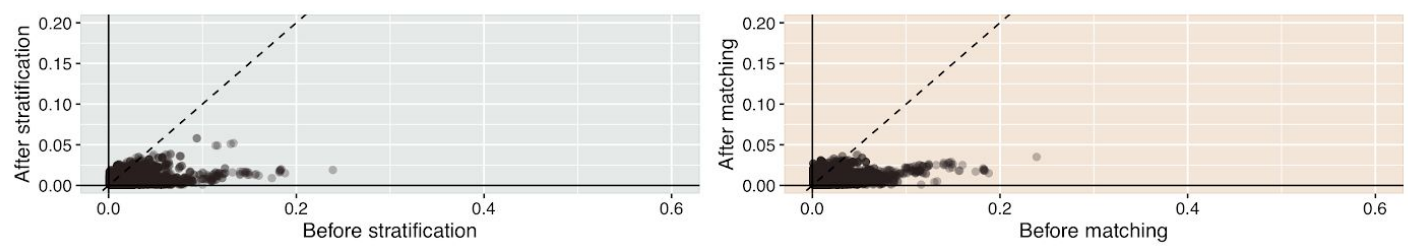

$\frac{\infty}{D}$
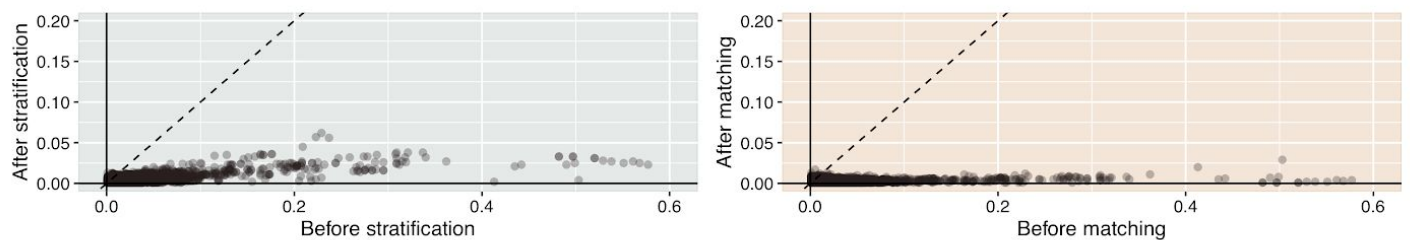

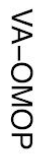
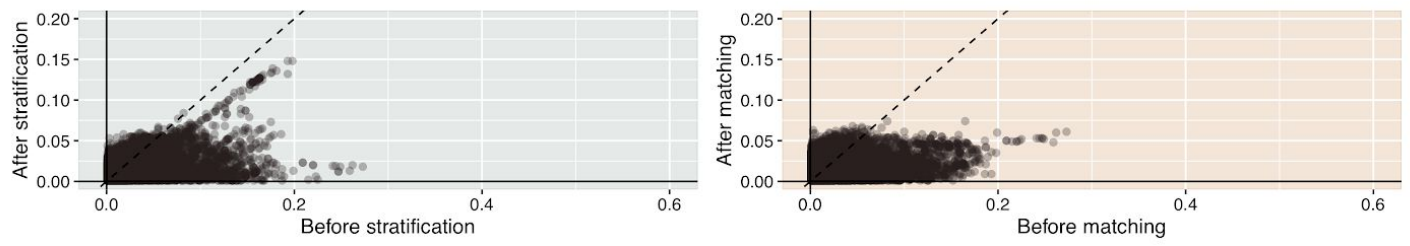

อุ 
medRxiv preprint doi: https://doi.org/10.1101/2020.06.11.20125849; this version posted June 12, 2020. The copyright holder for this preprint (which was not certified by peer review) is the author/funder, who has granted medRxiv a license to display the preprint in perpetuity.

It is made available under a CC-BY-NC 4.0 International license .

Table 3. Relative risk of COVID-19 diagnosis for ACE inhibitor, ARB, CCB and THZ prevalent-use. We report calibrated hazard ratios (HRs) and their $95 \%$ confidence intervals (Cls) and calibrated $p$-value $(P)$ for both monotherapy and in-combination cohort definitions, with propensity score (PS) stratification or matching and across data sources. Grayed out entries do not pass study diagnostics

\begin{tabular}{|c|c|c|c|c|c|c|}
\hline & \multicolumn{3}{|c|}{ PS-stratified } & \multicolumn{3}{|c|}{ PS-matched } \\
\hline & $\mathrm{HR}$ & $95 \% \mathrm{Cl}$ & $p$ & $\mathrm{HR}$ & $95 \% \mathrm{Cl}$ & $p$ \\
\hline \multicolumn{7}{|c|}{ ACE/ARB vs $\mathrm{CCB} / \mathrm{THZ}$} \\
\hline \multicolumn{7}{|l|}{ Monotherapy } \\
\hline SIDIAP & 1.02 & $(0.86-1.21)$ & 0.76 & 1.16 & $(0.93-1.44)$ & 0.24 \\
\hline VA-OMOP & 0.91 & $(0.71-1.17)$ & 0.48 & 1.06 & $(0.76-1.46)$ & 0.74 \\
\hline CUIMC & 1.46 & $(0.81-2.62)$ & 0.21 & 0.67 & $(0.20-2.20)$ & 0.53 \\
\hline Meta-analysis & 0.98 & $(0.84-1.14)$ & 0.76 & 1.10 & $(0.92-1.32)$ & 0.31 \\
\hline \multicolumn{7}{|l|}{ + Combination } \\
\hline SIDIAP & 1.06 & $(0.92-1.24)$ & 0.47 & 1.02 & $(0.85-1.23)$ & 0.76 \\
\hline VA-OMOP & 0.98 & $(0.81-1.18)$ & 0.80 & 1.03 & $(0.83-1.29)$ & 0.77 \\
\hline CUIMC & 1.28 & $(0.86-1.90)$ & 0.26 & 2.36 & $(0.98-5.68)$ & 0.06 \\
\hline Meta-analysis & 1.01 & $(0.90-1.15)$ & 0.81 & 1.09 & $(0.84-1.41)$ & 0.54 \\
\hline \multicolumn{7}{|l|}{ ACE vs CCB/THZ } \\
\hline \multicolumn{7}{|l|}{ Monotherapy } \\
\hline SIDIAP & 1.05 & $(0.88-1.25)$ & 0.68 & 1.14 & $(0.90-1.43)$ & 0.34 \\
\hline VA-OMOP & 0.77 & $(0.57-1.03)$ & 0.07 & 1.00 & $(0.70-1.44)$ & 0.96 \\
\hline CUIMC & 0.90 & $(0.40-2.00)$ & 0.78 & 0.92 & $(0.24-3.48)$ & 0.85 \\
\hline Meta-analysis & 0.91 & $(0.68-1.21)$ & 0.51 & 1.08 & $(0.89-1.31)$ & 0.45 \\
\hline \multicolumn{7}{|l|}{ + Combination } \\
\hline SIDIAP & 0.98 & $(0.86-1.12)$ & 0.75 & 0.95 & $(0.79-1.15)$ & 0.66 \\
\hline VA-OMOP & 0.91 & $(0.75-1.10)$ & 0.33 & 0.87 & $(0.70-1.08)$ & 0.21 \\
\hline CUIMC & 0.65 & $(0.38-1.12)$ & 0.13 & 0.45 & $(0.17-1.18)$ & 0.11 \\
\hline Meta-analysis & 0.95 & $(0.83-1.07)$ & 0.38 & 0.88 & $(0.75-1.04)$ & 0.14 \\
\hline \multicolumn{7}{|l|}{ ARB vs $\mathrm{CCB} / \mathrm{THZ}$} \\
\hline \multicolumn{7}{|l|}{ Monotherapy } \\
\hline SIDIAP & 1.01 & $(0.79-1.30)$ & 0.76 & 0.98 & $(0.69-1.39)$ & 0.81 \\
\hline VA-OMOP & 1.11 & $(0.78-1.58)$ & 0.57 & 1.18 & $(0.80-1.76)$ & 0.41 \\
\hline CUIMC & 1.72 & $(0.87-3.40)$ & 0.14 & 2.25 & $(0.43-11.6)$ & 0.34 \\
\hline Meta-analysis & 1.10 & $(0.89-1.35)$ & 0.40 & 1.16 & $(0.89-1.50)$ & 0.28 \\
\hline \multicolumn{7}{|l|}{ + Combination } \\
\hline SIDIAP & 1.08 & $(0.89-1.31)$ & 0.47 & 1.06 & $(0.84-1.33)$ & 0.65 \\
\hline VA-OMOP & 1.21 & $(0.99-1.49)$ & 0.07 & 1.17 & $(0.93-1.47)$ & 0.19 \\
\hline CUIMC & 1.69 & $(1.12-2.55)$ & 0.01 & 1.31 & $(0.61-2.85)$ & 0.51 \\
\hline Meta-analysis & 1.08 & $(0.89-1.31)$ & 0.49 & 1.16 & $(0.99-1.36)$ & 0.08 \\
\hline \multicolumn{7}{|l|}{ ACE vs ARB } \\
\hline \multicolumn{7}{|l|}{ Monotherapy } \\
\hline SIDIAP & 1.05 & $(0.83-1.33)$ & 0.70 & 1.01 & $(0.77-1.32)$ & 0.79 \\
\hline VA-OMOP & 0.73 & $(0.51-1.04)$ & 0.09 & 0.75 & $(0.52-1.10)$ & 0.15 \\
\hline CUIMC & 0.61 & $(0.27-1.38)$ & 0.27 & 0.22 & $(0.02-2.63)$ & 0.24 \\
\hline Meta-analysis & 0.85 & $(0.69-1.05)$ & 0.14 & 0.86 & $(0.69-1.07)$ & 0.18 \\
\hline \multicolumn{7}{|l|}{+ Combination } \\
\hline SIDIAP & 0.93 & $(0.79-1.10)$ & 0.46 & 0.95 & $(0.74-1.22)$ & 0.67 \\
\hline VA-OMOP & 0.84 & $(0.71-0.99)$ & 0.04 & 0.85 & $(0.71-1.02)$ & 0.08 \\
\hline CUIMC & 0.58 & $(0.38-0.87)$ & 0.01 & 0.54 & $(0.21-1.36)$ & 0.20 \\
\hline Meta-analysis & 0.88 & $(0.79-0.99)$ & 0.03 & 0.87 & $(0.77-0.99)$ & 0.04 \\
\hline
\end{tabular}


medRxiv preprint doi: https://doi.org/10.1101/2020.06.11.20125849; this version posted June 12, 2020. The copyright holder for this preprint (which was not certified by peer review) is the author/funder, who has granted medRxiv a license to display the preprint in perpetuity.

It is made available under a CC-BY-NC 4.0 International license .

Figure 3. Relative risk of COVID-19-related outcomes for ACE inhibitor, ARB, CCB and THZ prevalent-use across data sources. Outcomes are COVID-19 diagnosis, COVID-19 hospitalization (+Hospital), patients hospitalized with pneumonia (PNA) and patients hospitalized with pneumonia, acute respiratory distress syndrome, acute kidney injury or sepsis (PAAS). We plot calibrated hazard ratios (circles) and their $95 \%$ confidence intervals labeled by propensity score (PS) adjustment method (black/white). Grayed out entries do not pass study diagnostics.

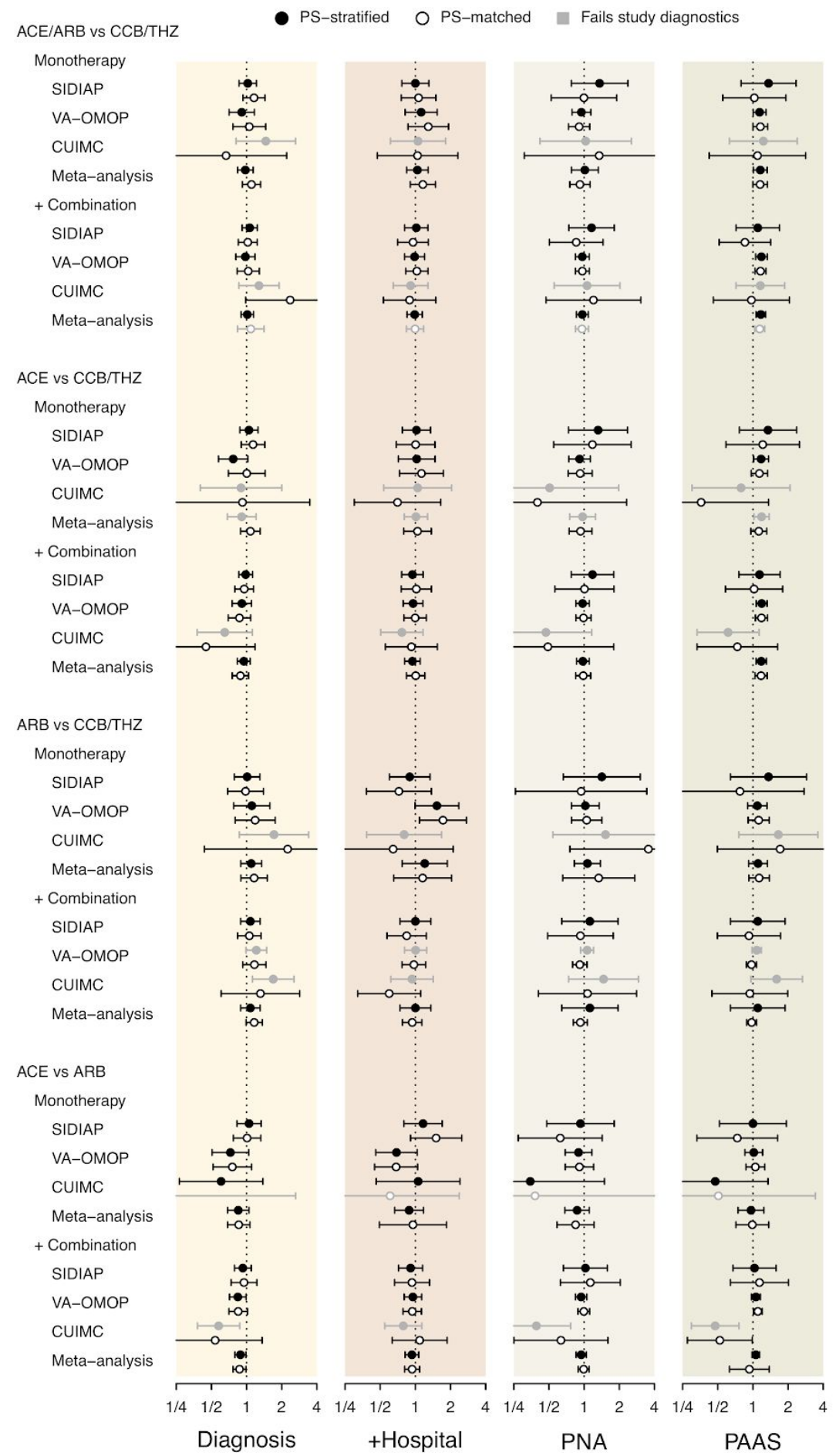


medRxiv preprint doi: https://doi.org/10.1101/2020.06.11.20125849; this version posted June 12, 2020. The copyright holder for this preprint (which was not certified by peer review) is the author/funder, who has granted medRxiv a license to display the preprint in perpetuity. It is made available under a CC-BY-NC 4.0 International license .

\section{Discussion}

\section{Summary of results}

In this multicenter cohort study following more than 1.1 million hypertensive patients from the US and Spain, we observed no clear increased risk of COVID-19 diagnosis, hospitalization, or subsequent complications associated with the outpatient prevalent ACE or ARB use. The clinical implication of this study is that patients should not halt their ACE or ARB therapy despite previously posited mechanisms of increased COVID-19 risk.

We observed one nominally significant meta-analysis difference, that use of ACE combination therapy had a lower risk of COVID-19 diagnosis when compared with ARB combination therapy use. There was, however, no corresponding difference detected in hospitalization or complications. Therefore, the observed association may be due to chance or residual bias. Even if true, there is only a $12 \%$ difference and therefore favoring ACE over ARB for mitigating COVID-19 is not strongly supported by our result.

\section{Comparison with other literature}

Four studies assessing the risk of Covid-19 infection among ACE/ARB use have been published originating from Italy, Spain and the US (de Abajo et al. 2020; Gnavi et al. 2020; Mancia et al. 2020; Mehra et al. 2020a; Reynolds et al. 2020). After adjustment for the higher prevalence of cardiovascular conditions in COVID-19 patients, ACE and ARB use was not associated with an increased risk of COVID-19 diagnosis. These case-control studies included only a limited number of covariates for model adjustment. Only two studies have compared the risk of COVID-19 susceptibility in ACE/ARB use with an active comparator (de Abajo et al. 2020; Khera et al. 2020a). In this context, comparing patients with similarly-indicated treatments is critical for reducing the risk of bias resulting from confounding by indication (e.g. hypertension), where the absence of treatment indicates either too mild disease to warrant pharmacological treatment (e.g. mild hypertension under control with lifestyle and diet changes), the presence of contraindications, or extreme frailty precluding the use of preventative medicines (e.g. at end-of-life) (Crump et al. 2009; Glynn et al. 2001; Petersen et al. 2012; Yoshida, Solomon, and Kim 2015). Indeed de Abajo et al. clearly demonstrates that compared to other antihypertensive use, non-use was associated with a significantly reduced risk of COVID-19 hospitalization with estimated odds ratios for severe and less severe cases of $0.48(0.34-0.69)$ and $0.57(0.43-0.75)$ respectively (de Abajo et al. 2020). 
medRxiv preprint doi: https://doi.org/10.1101/2020.06.11.20125849; this version posted June 12, 2020. The copyright holder for this preprint (which was not certified by peer review) is the author/funder, who has granted medRxiv a license to display the preprint in perpetuity. It is made available under a CC-BY-NC 4.0 International license .

While no previous study has directly compared the risk of COVID-19 diagnosis between ACE and ARB use, several studies have reported lower point estimates associated with ACEs than for ARBs. These odds ratios range from 0.61 to 0.92 for ACEs and 0.89 to 1.10 for ARB (Mehta et al. 2020; Khera et al. 2020b; Gnavi et al. 2020; de Abajo et al. 2020). However, not all observational studies have suggested a differential effect between ACE and ARB use (Mancia et al. 2020).

ACEs and ARBs have different effects on angiotensin II, the primary substrate of ACE2, required by SARS-CoV-2 to enter human cells (Vaduganathan et al. 2020). Animal models have suggested that while ACEs increase ACE2 gene expression, they do not alter ACE2 activity, unlike ARBs, providing a potential mechanism for why differential effects might occur (Ferrario et al. 2005); (Rice et al. 2004). However, recent studies in humans have identified no difference in ACE2 levels following exposure to ACE or ARB use (Emilsson et al. 2020); (Gill et al. 2020). Therefore, our findings could also be explained by residual confounding, as suggested by recent comparisons of the incidence of Staphylococcus aureus infection and other outcomes between $A C E$ and $A R B$ use which suggest that $A R B$ is not a perfect comparator for ACE, although no large scale PS-adjustment was used (Bidulka et al. 2020).

Furthermore, one study has reported an increased risk of COVID-19 hospitalization and ICU admission associated with use of ACE and ARB (Mehta et al. 2020). While we did not observe a consistent increased risk of hospitalization, we did observe an increased risk of PAAS largely driven by ACE use compared to $\mathrm{CCB} / \mathrm{THZ}$ use. This may be related to the higher incidence of AKI associated with ACE use as no increased risk was observed for pneumonia, and AKI would be significantly more frequent than ARDS or sepsis.

\section{Strengths and limitations}

We used an open science community approach to design a set of analyses consistently applied across a network of observational databases to generate results that can be directly compared and interpreted in aggregate. These analyses employed active comparators to reduce confounding by indication and is the first to apply large-scale propensity adjustment with full diagnostics and a large set of negative control experiments. We published the study protocol ahead of time and kept results blinded when assessing PS diagnostics helping to address concerns about reproducibility, robustness and transparency that have recently emerged (Rubin 2020; Mehra et al. 2020). We examined outpatient prevalent antihypertensive use because a new-user design in the context of COVID-19 that has widely affected the provision of routine care is infeasible. Therefore mediators on the causal pathway between exposure and outcome may be included in the adjustment. This may not necessarily result in bias in this 
medRxiv preprint doi: https://doi.org/10.1101/2020.06.11.20125849; this version posted June 12, 2020. The copyright holder for this preprint (which was not certified by peer review) is the author/funder, who has granted medRxiv a license to display the preprint in perpetuity.

setting however, as COVID-19 is a new illness and will not have affected the decision to initiate one drug over another and no depletion of susceptibles will have occurred. Similarly, biological mechanisms relating to ACE2 expression may require chronic exposure, hindering a new-user design. Prior treatment remains highly correlated with many baseline features that our large-scale propensity model considers when balancing patients and can provide some protection against this potential bias.

Further, we defined COVID-19 diagnosis through the presence of diagnostic codes or test positive results that will underestimate the number of true COVID-19 cases, the extent of which will vary by site due to differences in testing strategies. To address this potential limitation, we included a hospitalization-based COVID-19 outcome and observed similar results. Finally, we defined drug exposures by recorded prescriptions and we have no information on adherence. While we have used a rigorous approach (Suchard et al. 2019) to observational research, residual confounding is still possible.

\section{Clinical implications and conclusions}

Our findings stand in agreement with regulatory and clinical society advice that ACE and ARB therapy should be continued in light of COVID-19. Further, the marginal difference between ACEs and ARBs does not warrant class switching to reduce COVID-19 susceptibility. 
medRxiv preprint doi: https://doi.org/10.1101/2020.06.11.20125849; this version posted June 12, 2020. The copyright holder for this preprint (which was not certified by peer review) is the author/funder, who has granted medRxiv a license to display the preprint in perpetuity. It is made available under a CC-BY-NC 4.0 International license.

\section{Funding}

Dr. Morales is funded by a Wellcome Trust Clinical Research Career Development Fellowship (Grant 214588/Z/18/Z) and has received support from the National Institute for Health Research, Scottish Chief Scientist Office and Tenovus Scotland unrelated to this work. Drs. Conover, Weaver, Sena, Schuemie and Ryan are employees of Janssen Research \& Development. Dr. Suchard receives grants from the National Science Foundation, National Institutes of Health and IQVIA and consults for Janssen Research \& Development and Private Health Management. Dr. Hripcsak received a grant for this work from the US National Institutes of Health (R01 LM006910) and a grant for other work from Janssen Research \& Development. This work was supported by the Bio Industrial Strategic Technology Development Program (20001234) funded by the Ministry of Trade, Industry \& Energy (MOTIE, Korea) and a grant from the Korea Health Technology R\&D Project through the Korea Health Industry Development Institute (KHIDI), funded by the Ministry of Health \& Welfare, Republic of Korea [grant number: HI16C0992]. Dr. Prieto-Alhambra receives support from NIHR Senior Research Fellowship (SRF-2018-11-ST2-004, DPA). This project has received support from the European Health Data and Evidence Network (EHDEN) project. EHDEN received funding from the Innovative Medicines Initiative 2 Joint Undertaking (JU) under grant agreement No 806968. The JU receives support from the European Union's Horizon 2020 research and innovation programme and EFPIA. This project is funded by the Health Department from the Generalitat de Catalunya with a grant for research projects on SARS-CoV-2 and COVID-19 disease organized by the Direcció General de Recerca i Innovació en Salut. The University of Oxford and Ajou University received grants related to this work from the Bill \& Melinda Gates Foundation (Investment ID INV-016201 and INV-016284). The University of Oxford also received partial support from the UK National Institute for Health Research (NIHR) Oxford Biomedical Research Centre. Dr. Williams is supported by the US National Institutes of Health (U54TR002354). Dr. Lane is supported by Versus Arthritis (Clinical Research Fellowship 21605) and the Medical Research Council (Doctoral Research Programme MR/K501256/1). Dr. Pratt received grants from the Australian National Health and Medical Research Council GNT1157506. The views and opinions expressed are those of the authors and do not necessarily reflect those of the NIHR Academy programme, NIHR, Bill \& Melinda Gates Foundation, US Department of Veterans Affairs, United States Government, NHS, National Institutes of Health or the Department of Health, England. 
medRxiv preprint doi: https://doi.org/10.1101/2020.06.11.20125849; this version posted June 12, 2020. The copyright holder for this preprint (which was not certified by peer review) is the author/funder, who has granted medRxiv a license to display the preprint in perpetuity. It is made available under a CC-BY-NC 4.0 International license .

\section{Acknowledgements}

We acknowledge the tremendous work and dedication of the 350 participants from 30 nations in the March 2020 OHDSI COVID-19 Virtual Study-a-thon (https://www.ohdsi.org/covid-19-updates/), without whom this study could not have been realized.

\section{Ethical Approval}

All data partners received IRB approval or waiver in accordance with their institutional governance guidelines. Use of the SIDIAP data source was approved by the Clinical Research Ethics Committee of IDIAPJGol (project code: 20/070-PCV). Use of the VA-OMOP data source was reviewed by the Department of Veterans Affairs Central Institutional Review Board (IRB) and was determined to meet the criteria for exemption under Exemption Category 4(3) and approved the request for Waiver of HIPAA Authorization. Use of the CUIMC data source was approved by the Columbia University Institutional Review Board as an OHDSI network study (IRB\# AAAO7805).

\section{Supplementary Material}

Available at:

https://github.com/ohdsi-studies/Covid19lcarius/blob/master/Documents/SusceptibilitySupple $\underline{\text { ment.pdf }}$

\section{References}

Abajo, Francisco J. de, Sara Rodríguez-Martín, Victoria Lerma, Gina Mejía-Abril, Mónica Aguilar, Amelia García-Luque, Leonor Laredo, et al. 2020. “Use of Renin-angiotensin-aldosterone System Inhibitors and Risk of COVID-19 Requiring Admission to Hospital: A Case-Population Study." The Lancet 395 (10238): 1705-14.

Austin, Peter C. 2009. "Using the Standardized Difference to Compare the Prevalence of a Binary Variable Between Two Groups in Observational Research." Communications in Statistics - Simulation and Computation. https://doi.org/10.1080/03610910902859574. 
medRxiv preprint doi: https://doi.org/10.1101/2020.06.11.20125849; this version posted June 12, 2020. The copyright holder for this preprint (which was not certified by peer review) is the author/funder, who has granted medRxiv a license to display the preprint in perpetuity. It is made available under a CC-BY-NC 4.0 International license .

Bauer, Axel, and Steffen Massberg. n.d. "Stopping ACE-Inhibitors in COVID-19." Accessed June 2, 2020. https://clinicaltrials.gov/ct2/show/NCT04353596.

Bidulka, Patrick, Masao Iwagami, Kathryn E. Mansfield, Fotini Kalogirou, Angel Y. S. Wong, Ian J. Douglas, Liam Smeeth, Charlotte Summers, and Laurie A. Tomlinson. 2020. "Comparisons of Staphylococcus Aureus Infection and Other Outcomes between Users of Angiotensin-Converting-Enzyme Inhibitors and Angiotensin II Receptor Blockers: Lessons for COVID-19 from a Nationwide Cohort Study." Wellcome Open Research 5 (77): 77.

Crump, R. K., V. J. Hotz, G. W. Imbens, and O. A. Mitnik. 2009. "Dealing with Limited Overlap in Estimation of Average Treatment Effects." Biometrika. https://doi.org/10.1093/biomet/asn055.

DerSimonian, Rebecca, and Nan Laird. 1986. "Meta-Analysis in Clinical Trials." Controlled Clinical Trials. https://doi.org/10.1016/0197-2456(86)90046-2.

Dooley, Hannah, Karla Lee, Maxim Freidin, Gibran Hemani, Amy Roberts, Julien Lavigne du Cadet, Alessia Visconti, et al. n.d. "ACE Inhibitors, ARBs and Other Anti-Hypertensive Drugs and Novel COVID-19: An Association Study from the COVID Symptom Tracker App in 2,215,386 Individuals." Accessed April 23, 2020. https://doi.org/10.2139/ssrn.3583469.

Emilsson, Valur, Elias F. Gudmundsson, Thor Aspelund, Brynjolfur G. Jonsson, Alexander Gudjonsson, Lenore J. Launer, Lori L. Jennings, Valborg Gudmundsdottir, and Vilmundur Gudnason. 2020. "Antihypertensive Medication Uses and Serum ACE2 Levels." medRxiv. https://www.medrxiv.org/content/10.1101/2020.05.21.20108738v1.abstract.

European Medicines Agency. n.d. "EMA Advises Continued Use of Medicines for Hypertension, Heart or Kidney Disease during COVID-19 Pandemic." Accessed June 2, 2020. https://www.ema.europa.eu/en/news/ema-advises-continued-use-medicines-hypertensio n-heart-kidney-disease-during-covid-19-pandemic.

European Society of Cardiology. n.d. "Position Statement of the ESC Council on Hypertension on ACE-Inhibitors and Angiotensin Receptor Blockers." Accessed June 2, 2020. ESC. Available at:

https://www.escardio.org/Councils/Council-on-Hypertension-(CHT)/News/position-statem ent-of-the-esc-council-on-hypertension-on-ace-inhibitors-and-ang Accessed 01/06/2020.

Fang, Lei, George Karakiulakis, and Michael Roth. 2020. "Are Patients with Hypertension and Diabetes Mellitus at Increased Risk for COVID-19 Infection?" The Lancet Respiratory Medicine. https://doi.org/10.1016/s2213-2600(20)30116-8.

Ferrario, Carlos M., Jewell Jessup, Mark C. Chappell, David B. Averill, K. Bridget Brosnihan, E. Ann Tallant, Debra I. Diz, and Patricia E. Gallagher. 2005. "Effect of Angiotensin-Converting Enzyme Inhibition and Angiotensin II Receptor Blockers on Cardiac Angiotensin-Converting Enzyme 2." Circulation 111 (20): 2605-10.

Gill, Dipender, Marios Arvanitis, Paul Carter, Ana I. Hernandez Cordero, Brian Jo, Ville Karhunen, Susanna C. Larsson, et al. 2020. “ACE Inhibition and Cardiometabolic Risk Factors, Lung ACE2 and TMPRSS2 Gene Expression, and Plasma ACE2 Levels: A Mendelian Randomization Study." medRxiv.

https://www.medrxiv.org/content/10.1101/2020.04.10.20059121v1?rss=1.

Glynn, R. J., E. L. Knight, R. Levin, and J. Avorn. 2001. "Paradoxical Relations of Drug Treatment with Mortality in Older Persons." Epidemiology 12 (6): 682-89.

Gnavi, Roberto, Moreno Demaria, Roberta Picariello, Marco Dalmasso, Fulvio Ricceri, and Giuseppe Costa. 2020. "Therapy with Agents Acting on the Renin-Angiotensin System and 
medRxiv preprint doi: https://doi.org/10.1101/2020.06.11.20125849; this version posted June 12, 2020. The copyright holder for this preprint (which was not certified by peer review) is the author/funder, who has granted medRxiv a license to display the preprint in perpetuity. It is made available under a CC-BY-NC 4.0 International license .

Risk of SARS-CoV-2 Infection." Clinical Infectious Diseases: An Official Publication of the Infectious Diseases Society of America, May. https://doi.org/10.1093/cid/ciaa634.

Guo, Tao, Yongzhen Fan, Ming Chen, Xiaoyan Wu, Lin Zhang, Tao He, Hairong Wang, Jing Wan, Xinghuan Wang, and Zhibing Lu. 2020. "Cardiovascular Implications of Fatal Outcomes of Patients With Coronavirus Disease 2019 (COVID-19)." JAMA Cardiology. https://doi.org/10.1001/jamacardio.2020.1017.

Hoffmann, Markus, Hannah Kleine-Weber, Simon Schroeder, Nadine Krüger, Tanja Herrler, Sandra Erichsen, Tobias S. Schiergens, et al. 2020. "SARS-CoV-2 Cell Entry Depends on ACE2 and TMPRSS2 and Is Blocked by a Clinically Proven Protease Inhibitor." Cell. https://doi.org/10.1016/j.cell.2020.02.052.

Hripcsak, George, Jon D. Duke, Nigam H. Shah, Christian G. Reich, Vojtech Huser, Martijn J. Schuemie, Marc A. Suchard, et al. 2015. "Observational Health Data Sciences and Informatics (OHDSI): Opportunities for Observational Researchers." Studies in Health Technology and Informatics 216: 574-78.

Ishiyama, Yuichiro, Patricia E. Gallagher, David B. Averill, E. Ann Tallant, K. Bridget Brosnihan, and Carlos M. Ferrario. 2004. "Upregulation of Angiotensin-Converting Enzyme 2 after Myocardial Infarction by Blockade of Angiotensin II Receptors." Hypertension 43 (5): 970-76.

Khera, Rohan, Callahan Clark, Yuan Lu, Yinglong Guo, Sheng Ren, Brandon Truax, Erica S. Spatz, et al. 2020. "Association of Angiotensin-Converting Enzyme Inhibitors and Angiotensin Receptor Blockers with the Risk of Hospitalization and Death in Hypertensive Patients with Coronavirus Disease-19." medRxiv, May, 2020.05.17.20104943.

Li, Wenhui, Michael J. Moore, Natalya Vasilieva, Jianhua Sui, Swee Kee Wong, Michael A. Berne, Mohan Somasundaran, et al. 2003. "Angiotensin-Converting Enzyme 2 Is a Functional Receptor for the SARS Coronavirus." Nature 426 (6965): 450-54.

Mancia, Giuseppe, Federico Rea, Monica Ludergnani, Giovanni Apolone, and Giovanni Corrao. 2020. "Renin-Angiotensin-Aldosterone System Blockers and the Risk of Covid-19." The New England Journal of Medicine, May. https://doi.org/10.1056/NEJMoa2006923.

Mehra, Mandeep R., Sapan S. Desai, Sreyram Kuy, Timothy D. Henry, and Amit N. Patel. 2020. "Retraction: Cardiovascular Disease, Drug Therapy, and Mortality in Covid-19. N Engl J Med. DOI: 10.1056/NEJMoa2007621." The New England Journal of Medicine, June. https://doi.org/10.1056/NEJMc2021225.

Mehta, Neil, Ankur Kalra, Amy S. Nowacki, Scott Anjewierden, Zheyi Han, Pavan Bhat, Andres E. Carmona-Rubio, et al. 2020. "Association of Use of Angiotensin-Converting Enzyme Inhibitors and Angiotensin II Receptor Blockers With Testing Positive for Coronavirus Disease 2019 (COVID-19)." JAMA Cardiology. https://doi.org/10.1001/jamacardio.2020.1855.

Petersen, Maya L., Kristin E. Porter, Susan Gruber, Yue Wang, and Mark J. Van Der Laan. 2012. "Diagnosing and Responding to Violations in the Positivity Assumption." Statistical Methods in Medical Research 21 (1): 31-54.

Reynolds, Harmony R., Samrachana Adhikari, Claudia Pulgarin, Andrea B. Troxel, Eduardo Iturrate, Stephen B. Johnson, Anaïs Hausvater, et al. 2020.

"Renin-Angiotensin-Aldosterone System Inhibitors and Risk of Covid-19." The New England Journal of Medicine, May. https://doi.org/10.1056/NEJMoa2008975.

Rice, Gillian I., Daniel A. Thomas, Peter J. Grant, Anthony J. Turner, and Nigel M. Hooper. 2004. 
medRxiv preprint doi: https://doi.org/10.1101/2020.06.11.20125849; this version posted June 12, 2020. The copyright holder for this preprint (which was not certified by peer review) is the author/funder, who has granted medRxiv a license to display the preprint in perpetuity. It is made available under a CC-BY-NC 4.0 International license .

"Evaluation of Angiotensin-Converting Enzyme (ACE), Its Homologue ACE2 and Neprilysin in Angiotensin Peptide Metabolism." Biochemical Journal 383 (Pt 1): 45-51.

Rosenbaum, Paul R., and Donald B. Rubin. 1983. "The Central Role of the Propensity Score in Observational Studies for Causal Effects." Biometrika.

https://doi.org/10.1093/biomet/70.1.41.

Ruan, Qiurong, Kun Yang, Wenxia Wang, Lingyu Jiang, and Jianxin Song. 2020. "Clinical

Predictors of Mortality due to COVID-19 Based on an Analysis of Data of 150 Patients from Wuhan, China." Intensive Care Medicine. https://doi.org/10.1007/s00134-020-05991-x.

Rubin, Eric J. 2020. "Expression of Concern: Mehra MR et Al. Cardiovascular Disease, Drug Therapy, and Mortality in Covid-19. N Engl J Med. DOI: 10.1056/NEJMoa2007621." The New England Journal of Medicine, June. https://doi.org/10.1056/NEJMe2020822.

Schuemie, Martijn J., George Hripcsak, Patrick B. Ryan, David Madigan, and Marc A. Suchard. 2016. "Robust Empirical Calibration of P-Values Using Observational Data." Statistics in Medicine.

Schuemie, Martijn J., Patrick B. Ryan, William DuMouchel, Marc A. Suchard, and David Madigan. 2014. "Interpreting Observational Studies: Why Empirical Calibration Is Needed to Correct P-Values." Statistics in Medicine 33 (2): 209-18.

Schuemie, Martijn J., Patrick B. Ryan, George Hripcsak, David Madigan, and Marc A. Suchard. 2018. "Improving Reproducibility by Using High-Throughput Observational Studies with Empirical Calibration." Philosophical Transactions. Series A, Mathematical, Physical, and Engineering Sciences 376 (2128). https://doi.org/10.1098/rsta.2017.0356.

Shi, Shaobo, Mu Qin, Bo Shen, Yuli Cai, Tao Liu, Fan Yang, Wei Gong, et al. 2020. "Association of Cardiac Injury With Mortality in Hospitalized Patients With COVID-19 in Wuhan, China." JAMA Cardiology. https://doi.org/10.1001/jamacardio.2020.0950.

Soler, María José, Minghao Ye, Jan Wysocki, Josette William, Josep Lloveras, and Daniel Batlle. 2009. "Localization of ACE2 in the Renal Vasculature: Amplification by Angiotensin II Type 1 Receptor Blockade Using Telmisartan." American Journal of Physiology. Renal Physiology 296 (2): F398-405.

Suchard, Marc A., Martijn J. Schuemie, Harlan M. Krumholz, Seng Chan You, Ruijun Chen, Nicole Pratt, Christian G. Reich, et al. 2019. "Comprehensive Comparative Effectiveness and Safety of First-Line Antihypertensive Drug Classes: A Systematic, Multinational, Large-Scale Analysis." The Lancet 394 (10211): 1816-26.

Suchard, Marc A., Shawn E. Simpson, Ivan Zorych, Patrick Ryan, and David Madigan. 2013.

"Massive Parallelization of Serial Inference Algorithms for a Complex Generalized Linear Model." ACM Transactions on Modeling and Computer Simulation 23 (1): 10:1-10:17.

Sukumaran, Vijayakumar, Hirotsugu Tsuchimochi, Eisuke Tatsumi, Mikiyasu Shirai, and James T.

Pearson. 2017. "Azilsartan Ameliorates Diabetic Cardiomyopathy in Young Db/db Mice through the Modulation of ACE-2/ANG 1-7/Mas Receptor Cascade." Biochemical Pharmacology. https://doi.org/10.1016/j.bcp.2017.07.022.

Sukumaran, Vijayakumar, Punniyakoti T. Veeraveedu, Narasimman Gurusamy, Ken 'ichi Yamaguchi, Arun Prasath Lakshmanan, Meilei Ma, Kenji Suzuki, Makoto Kodama, and Kenichi Watanabe. 2011. "Cardioprotective Effects of Telmisartan against Heart Failure in Rats Induced by Experimental Autoimmune Myocarditis through the Modulation of Angiotensin-Converting Enzyme-2/angiotensin 1-7/mas Receptor Axis." International Journal of Biological Sciences 7 (8): 1077-92. 
medRxiv preprint doi: https://doi.org/10.1101/2020.06.11.20125849; this version posted June 12, 2020. The copyright holder for this preprint (which was not certified by peer review) is the author/funder, who has granted medRxiv a license to display the preprint in perpetuity. It is made available under a CC-BY-NC 4.0 International license.

Sukumaran, Vijayakumar, Punniyakoti T. Veeraveedu, Arun Prasath Lakshmanan, Narasimman Gurusamy, Ken 'ichi Yamaguchi, Meilei Ma, Kenji Suzuki, Makoto Kodama, and Kenichi Watanabe. 2012. “Olmesartan Medoxomil Treatment Potently Improves Cardiac Myosin-Induced Dilated Cardiomyopathy via the Modulation of ACE-2 and ANG 1-7 Mas Receptor." Free Radical Research. https://doi.org/10.3109/10715762.2012.684878.

Tian, Yuxi, Martijn J. Schuemie, and Marc A. Suchard. 2018. "Evaluating Large-Scale Propensity Score Performance through Real-World and Synthetic Data Experiments." International Journal of Epidemiology. https://doi.org/10.1093/ije/dyy120.

Vaduganathan, Muthiah, Orly Vardeny, Thomas Michel, John J. V. McMurray, Marc A. Pfeffer, and Scott D. Solomon. 2020. "Renin-Angiotensin-Aldosterone System Inhibitors in Patients with Covid-19." The New England Journal of Medicine 382 (17): 1653-59.

Voss, E. A., R. D. Boyce, P. B. Ryan, J. van der Lei, P. R. Rijnbeek, and M. J. Schuemie. 2017. "Accuracy of an Automated Knowledge Base for Identifying Drug Adverse Reactions." Journal of Biomedical Informatics 66 (February): 72-81.

Vuille-dit-Bille, Raphael N., Simone M. Camargo, Luca Emmenegger, Tom Sasse, Eva Kummer, Julia Jando, Qeumars M. Hamie, et al. 2015. "Human Intestine Luminal ACE2 and Amino Acid Transporter Expression Increased by ACE-Inhibitors." Amino Acids 47 (4): 693-705.

Walker, Alexander, Patrick, Lauer, Hornbrook, Marin, Platt, Roger, Stang, and Schneeweiss. 2013. "A Tool for Assessing the Feasibility of Comparative Effectiveness Research." Comparative Effectiveness Research. https://doi.org/10.2147/cer.s40357.

Yoshida, Kazuki, Daniel H. Solomon, and Seoyoung C. Kim. 2015. "Active-Comparator Design and New-User Design in Observational Studies." Nature Reviews. Rheumatology 11 (7): 437-41.

Zhang, Peng, Lihua Zhu, Jingjing Cai, Fang Lei, Juan-Juan Qin, Jing Xie, Ye-Mao Liu, et al. 2020. "Association of Inpatient Use of Angiotensin Converting Enzyme Inhibitors and Angiotensin II Receptor Blockers with Mortality Among Patients With Hypertension Hospitalized With COVID-19." Circulation Research, April. https://doi.org/10.1161/CIRCRESAHA.120.317134.

Zhong, Jiu-Chang, Jia-Ying Ye, Hai-Yan Jin, Xi Yu, Hui-Min Yu, Ding-Liang Zhu, Ping-Jin Gao, et al. 2011. "Telmisartan Attenuates Aortic Hypertrophy in Hypertensive Rats by the Modulation of ACE2 and Profilin-1 Expression." Regulatory Peptides 166 (1-3): 90-97. 